\title{
олег Хома
}

\section{СПІНОЗА У ФОКУСІ НАЦІОНАЛЬНИХ ТРАДИЦІЙ.}

\section{Stetter, J., \& Ramond, C. (Eds.). (2019). Spinoza in 21st-century American and French philosophy: metaphysics, philosophy of mind, moral and political philosophy. London: Bloomsbury Academic.}

Протягом останнього десятиліття дослідження з філософії Спінози демонструють неабияку оригінальність у виборі тем. Наприклад, 2020 рік ознаменований кількома цікавими розвідками, яким, сподіваюся, в Україні буде приділено належну увагу ${ }^{1}$. Утім, книга під редакцією Жака Стетера і Шарля Рамона виділяється навіть на цьому тлі, оскільки $\epsilon$ першим досвідом свідомої взаємодії провідних національних традицій, що склалися в сучасному спінозознавстві. Традицій, що прагнуть набуги ледь не деякої суб'єктності й самоосмислення! Книга містить вельми істотно доопрацьовані матеріали дискусій, що відбулися під час конференції «Спіноза, Франція, Сполучені Штати» (університет Париж VIII, 2016).

Але появі такого видання не варто дивуватися, воно цілком відповідне духові часу. Нині ми є свідками становлення свого роду глобальних історико-філософських проектів ${ }^{2}$, що висловлюються англійською, але увиразнюють і зберігають унікальність тих національних дослідницьких підходів, що склалися в різних країнах протягом XIX-XX ст. Глобалізація насправді не нівелює цих традицій, а радше створює нові можливості для плідної взаємодії. Осмислення цієї ситуації є вкрай важливим для поліпшення історико-філософських досліджень в Україні. 3 украй низьким рівнем більшості «дослідницьких праць», зумовленим багаторічним свідомим (й інституційно закріпленим) ігноруванням базових професійних вимог, звісно ж, не можна миритися. Однак цілком природні вітчизняні спроби реформувати цей стан справ примітивно, орієнтовані на прості розв'язки. Раз у нас автаркія, давайте подолаємо іï, друкуючи свої дослідження переважно англійською (і бажано за кордоном - раз у нас криза експертизи). Але відсутність якісних досліджень - не проблема мови чи місця публікацій. Не помітно, наприклад, щоби провідні французькі чи німецькі історико-філософські часописи переходили суціль на англійську, раз переважна кількість

(C) О. Хома, 2020

${ }^{1}$ Ідеться про книги Стівена Надлера «Якнайменше думати про смерть: Спіноза про те, як жити і як померти» [Nadler 2020] і Димитріса Вардулакіса «Спіноза-епікуреєць: авторитет і користь в матеріалізмі» [Vardoulakis 2020]. На мій погляд, практична філософія Спінози зовсім не випадково потрапила нині у фокус активних дискусій. Адже потужний вплив нового натуралізму, яким позначене усе поле сучасних масових комунікацій, має свою ахіллесову п’яту: проблему обгрунтування цінностей. Як піддати все редукції, не редукувавши при цьому до якогось «базового» тваринного рівня ті цінності, що роблять людей людьми, а не найкмітливішим видом приматів? Примітивні матеріалістичні відповіді на це питання швидко доходять абсурду. Натомість «високі» форми матеріалізму, на кшталт Спінозової, залишаються єдиною неексцентричною надією прибічників цього підходу. Проблема гідного життя $є$ ключовою причиною сучасної популярності Спінози.

2 Наприклад, автори книги вважають початком справжньої глобалізації спінозознавства 1986 рік, коли відбулася організована Д. Керлі і П.-Ф. Моро Чиказька конференція зі спінозознавства (xxv). I навіть сподіваючись, що сприйняття Спінози колись стане, кінець кінцем, «не американським чи французьким, а міжнародним» (p. хvii), автори виходять 3 теперішньої специфіки традицій як із деякого безсумнівного факту. 
світових історико-філософських публікацій англомовна. Адже йдеться про самодостатні (але не автаркічні) традиції, що тільки й можуть бути цікавими в глобальному масштабі ${ }^{3}$.

Збірка Стетера й Рамона є чудовим свідченням важливості якісних національних традицій для якісного глобального діалогу. Оригінальною є структура книги. Кожну 3 тринадцяти статей англомовних авторів, розподілених на чотири частини, що охоплюють основну філософську тематику Спінози, супроводжує відповідна їй стаття (A Response) французького дослідника ${ }^{4}$.

Укладачі збірки мають за мету «полегшення діалогу» між двома «видатними» спінозознавчими традиціями (р. ххіi). Вплив Спінози на французьку філософію XX ст. порівнюється з аналогічним впливом на філософію XVIII ст.: в останньому випадку нідерландський автор став одним з джерел радикального просвітництва, у першому Radical French Theory (p. xxiii). Описавши особливості історії французького (хxii-xxvi) й американського чи, радше, англомовного (xxvi-xxix) академічного спінозознавства, автори виводять із неї теперішню тематику досліджень. Французьке спінозознавство позначене передовсім впливом Матерона (наголошення на концепції conatus) i Дельоза, тобто французькі дослідники повсякчас схильні «віддалятися він здебільшого найшановніших і найкраще опрацьованих царин спінозознавчих дискусій - наприклад, від суперечок про статус атрибутів чи про несесітарианізм Спінози, - і тяжіти до більш нетипових царин, де менш відомі Спінозові праці, як-от Політичний тракmam, відіграють центральну роль» (p. xxvi). Однак найновіші тенденції полягають у

${ }^{3}$ Показовою в цьому сенсі є мотивація Сетера і Рамона: «Оскільки ми розуміли, що як американський, так і французький підхід до Спінози були особливо потужними, нам здалося, що настав час розпочати дискусію між ними» (p. ix). Цю дуже показову фразу варто запам'ятати і зрозуміти, що плідна дискусія між традиціями має перспективу лише тоді, коли вони обопільно визнають одна одну «особливо потужними». У цьому сенсі приклад наших західних колег з неангломовного світу (до якого належить і Україна) є свого роду дороговказом. Бо ми передовсім потребуємо саме потужної вітчизняної дослідницької традиції з розвиненою філософською мовою, численними якісними перекладами, справді оригінальними дослідженнями, активними дискусіями й широким спілкуванням із закордонними колегами на рівні як дослідницьких центрів, так і окремих дослідників. До речі, автори особливо наголошують на знаковій ролі фундаментальних перекладів Спінози для становлення національних традицій (p. xxii, xxiv, xxviii). Спроби ж просто зробити англомовними максимальну кількість національних філософських журналів, не змінивши ані їхньої якості, ані принципів відбору матеріалів, ані - головне - самої природи дослідницької праці є давно практикованим у нас типажем «потьомкінської дєрєвні», запозиченим аж ніяк не з західного досвіду.

4 Частина I. Метафізика. 1. Едвін Керлі, Перегляд Спінозової метафізики. - П'єр-Франсуа Моро, Про Спінозу, можливі світи і пантеїзм. 2. Майкл Делла Рокка, Невловимість [проблеми] єдиного і множинного в Спінози: субстанція, атрибут і модус. - Паскаль Северак, Яким чином щось існує. 3. Іихак Меламед, Найбільш ранній нарис Спінозової метафізики. - Моган Лерк, Акциденти і модифікації: додаткова примітка до аксіом 1 і 2 в Додатку I Короткого трактату. 4. Мартин Лін, Метафізичний раціоналізм. - Валері Дебюім, Ляйбніців принцип (достатньої) підстави і принцип тотожності нерозрізненних. 5. Саймон Дафi, Трансформація відношення у метафізиці Спінози. Селін Ерве, Сутність, варіації потуги й «Веcoming Other» у Спінози. Частина II. Філософія ума. 6. Елісон Пітерман, Два твердження Спінози щодо ума й тіла. - Жак Стетер, Головоломка у поглядах Спінози на проблему ума й тіла. 7. Нокс Піден, Спінозові істинні ідеї: переконливі конвергенції. - Паскаль Жійо, Альтюсер, Спіноза і картезіанський суб'єкт. 8. Майкл Розенталь, Спіноза про мисленнєві сутності [Entia Rationis] і виображення за аналогією. - Жаклін Латре, Analogia i Ens Rationis. Частина III. Моральна філософія. 9. Стівен Надлер, Спіноза про добро і зло. Лоренсо Вінсігера, Пізнання добра і зла. 10. Хасана Шарп, Благородство як свобода в Етиці Спінози. - Пріель Суамі, Благородне прочитання. Частина IV. Політична філософія. 11. Деніел Гарбер, Антропоморфізм, телеологія і забобон: політика покори в Богословсько-політичному трактаті Спінози. - Шанталь Жаке, Логіка забобонного, логіка благочестивого. 12. Стівен Барбен, <Твір Матерона> Індивід і спільнота та його американська спадщина. - Лоран Бов, Між Матероном і Спінозою: щось сталося. 13. Джонатан Ісраель, Формулювання двох засадових концептів радикального просвітництва Спінозою: наскільки він зобов'язаний політично-богословському контекстові голандської Золотої Доби? - Шарль Рамон, Парадоксальний радикалізм Спінози. 
поширенні спінозівських ідей на «позафілософські царини» (біологія, соціологія економіка) і спробах на цій основі по новому зрозуміти самі ці ідеї. До речі, у США аналогічні тенденції представлені працями нейродослідника Антоніо Дамасіо і психіатра Ірвіна Ялома (p. xxvii). У цілому ж, американське спінозознавство зосереджене передовсім на питаннях метафізики, які аналітична філософія намагалася викорінити протягом I-ї по. XX ст. Попри антиметафізичні тенденції у новітній французькій філософіï, автори стверджують, що інтерес до метафізичного раціоналізму Спінози нині $\epsilon$ потужним по обидва боки Атлантики. Іншими прикметними рисами спінозознавства у США є розвиток контекстуаалістських історико-філософських підходів (Д. Гарбер) і досліджень з моральної й політичної філософії Спінози (р. ххіх). Обидві ці тенденції теж можна вважати відступом від вузьких кліше ранньої аналітичної філософії.

Кожна пара статей цієї книги є унікальним фактом критичної взаємодії двох своєрідних традицій у спінозознавстіві. Тому я вельми раджу ознайомитися з цим виданням усім, хто цікавиться як модерною філософією, так і національними традиціями філософування.

\section{СПИСОК ЛІТЕРАТУРИ / REFERENCES}

Nadler, S. (2020). Think Least of Death: Spinoza on How to Live and How to Die. Princeton, NJ : Princeton University Press. https://doi.org/10.2307/j.ctvzgb70g

Stetter, J., \& Ramond, C. (Eds.). (2019). Spinoza in 21st-century American and French philosophy: metaphysics, philosophy of mind, moral and political philosophy. London: Bloomsbury Academic. https://doi.org/10.5040/9781350067332

Vardoulakis, D. (2020). Spinoza, the Epicurean: Authority and Utility in Materialism. Edinburgh: Edinburgh University Press.

Одержано / Received 17.08.2020

\section{Oleg Khoma}

Spinoza in the focus of national traditions. Stetter, J., \& Ramond, C. (Eds.). (2019). Spinoza in 21st-century American and French philosophy: metaphysics, philosophy of mind, moral and political philosophy. London: Bloomsbury Academic.

Review of Stetter, J., \& Ramond, C. (Eds.). (2019). Spinoza in 21st-century American and French philosophy: metaphysics, philosophy of mind, moral and political philosophy. London: Bloomsbury Academic.

\section{Олег Хома}

Спіноза у фокусі національних традицій. Stetter, J., \& Ramond, С. (Eds.). (2019). Spinoza in 21st-century American and French philosophy: metaphysics, philosophy of mind, moral and political philosophy. London: Bloomsbury Academic.

Огляд книги Stetter, J., \& Ramond, C. (Eds.). (2019). Spinoza in 21st-century American and French philosophy: metaphysics, philosophy of mind, moral and political philosophy. London: Bloomsbury Academic.

Oleg Khoma, Doctor of sciences in philosophy, Professor, Head of the Department of Philosophy and Humanities at Vinnitsia National Technical University.

Олег Хома, доктор філософських наук, завідувач кафедри філософії та гуманітарних наук Вінницького національного технічного університету.

e-mail: quid2anim@gmail.com 